\title{
LEADERSHIP COMPETENCE OF PROGYMNASIUM HEADS AS A FACTOR IN MAKING THE MANAGEMENT OF SCHOOL PERFORMANCE MORE EFFECTIVE
}

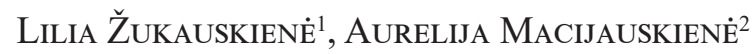 \\ Klaipeda University (Lithuania)
}

\begin{abstract}
The article focuses on the issue of the leadership competence of the heads of progymnasiums as a factor in making schools more effective. Progymnasium is part of the Lithuanian system, an institution of general education (Forms 1 to 8), an intermediate link between an elementary school and gymnasium, which differs from basic school in higher quality of activity, the created added value, and pupils' learning achievements. Quantitative research was conducted with the participation of 193 progymnasium teachers. The research revealed that the leadership competence of the heads of progymnasiums significantly contributed to making schools more effective in terms of participation in projects, favourable conditions for teacher initiatives, participation of community members in the self-evaluation process, creating conditions for teacher professional development, supporting and promoting initiatives, initiating the process of progress and achievement assessment, ensuring the coherence of the mission, vision, and values of the educational institution, the involvement of parents /guardians/ caregivers, promotion of communication and collaboration between community members, and the maintenance of sustainable relations with social partners. The obtained research findings are to be considered as relevant for seeking active expression of leadership of the school authorities and teachers and making progymnasiums more effective. KEYWORDS: progymnasium, the heads of progymnasium, leadership competence, making school effective.
\end{abstract}

JEL CODES: D83, M12

DOI:

Introduction

Rapid changes taking place in contemporary society affect education, which is directly related to the democratisation of society and performs the functions of cultural transfer, transformation, and social control. The effectiveness of educational institutions and the quality of each individual's learning and life (Nzok et al., 2015; Orhan-Karsak, 2017) directly depend on the way education is organised and on the self-expression of its participants. As one of the factors of change in educational institutions, teacher leadership has been increasingly accentuated (Sotrey, 2016; Leithwood, Mitgang, 2012; Lewis, Hill, 2012). Leaders of educational institutions are expected to create an environment and atmosphere in which educators will work more efficiently, students will learn willingly and seek academic excellence (Haynes et al., 2014), and the process of personality formation will be successful (Nemerowicz, Rosi, 2013).

In the 2010s, a number of changes took place in the Lithuanian education system, one of them being a new structure of the school network, legalised by the Republic of Lithuania Law on Education adopted in 2011 (Art. 41, para. 2), and the introduction of a new school type, i.e. progymnasium, alongside basic school. Progymnasium is an institution of general education for pupils in Forms 1 to 8. As laid out in Art 41 of the Law on Education of the Republic of Lithuania, the main purpose of that type of schools was to implement the basic education curriculum (or a part thereof) and to prepare pupils for further learning (Lietuvos Respublikos švietimo ịstatymas, 2011).

1 Lilia Žukauskienė. PhD, professor of the Department of Pedagogy, Faculty of Social Sciences and Humanities, Klaipeda University. Scientific interests: Educology. e-mail: lilia.zukauskiene@gmail.com

2 Aurelija Macijauskienè. Teacher of Klaipeda Lyceum, assistant of the Department of Pedagogy, Faculty of Social Sciences and Humanities, Klaipeda University. Scientific interests: Educology. 
Progymnasium was expected, upon concentrating children in accordance with age groups, to provide more favourable conditions for children's education and simultaneously to use the state and municipal funds much more efficiently. Progymnasium, like basic school, is an intermediate link between primary school and gymnasium (Progimnazijų ir pagrindinių mokyklų paskirtis ir vieta bendrojo ugdymo sistemoje, 2016).

In accordance with the external evaluation of performance by the National Agency for School Evaluation (NASE) (2015), the quality of the progymnasiums activities, the created added value, and pupil learning achievements were among the best compared to other types of schools. In basic schools, the quality of activities and pupil learning achievements were lower. The gap between the two types of schools was related to the social, economic, and cultural environment of pupils (Bendrojo ugdymo mokyklų veiklos kokybè. Nacionalinès mokyklų vertinimo agentūros metinis pranešimas, 2015).

Leadership became one of the goals of performance management at all levels of the education system, including progymnasium. Effective progymnasium performance management started to be associated with the school prestige, overcoming of emerging requirements, anticipating new directions of activity, and the characteristics, abilities, and competences of individuals performing activities. The focus of the current research is placed on the heads of progymnasiums who are primarily expected to lead the school in the implementation of innovations that are important to society as a whole.

The research addresses calls in the National Education Strategy 2013-2022 (Valstybine švietimo strategija 2013-2022 m., 2014) and the provisions of the Good School Concept (LR ŠMM ministro isakymas „Dèl geros mokyklos koncepcijos patvirtinimo“, 2015) for educational institutions to become learning communities, characterised by leadership and forming a different culture of education management. Lithuania s Progress Strategy „Lithuania 2030“ (LR Seimo nutarimas „Dẻl valstybinės pažangos strategijos „Lietuvos pažangos strategija „Lietuva 2030“patvirtinimo“, 2012) also emphasises the importance of leadership and managerial competencies in communities and institutions.

The issue of leadership in school performance management has been explored by researchers abroad (Arman et al., 2016; Storey, 2016; Everard et al., 2014; Haynes et al., 2014; Nemerowicz et al., 2013, etc.) and in Lithuania (Valuckienè et al., 2015; Skarbalienè, 2015; Savareikienè, 2013; Cibulskas et al., 2012; Malinauskienè et al., 2012 et al., etc.). The research revealed certain aspects of the issue such as the expression of the leadership qualities of the heads of schools (Nzok et al., 2015); the distribution of leadership positions in an educational institution (Everard et al., 2014); effective school leadership (Marzano et al., 2011) and others. According to Nedzinskaite (2013), the topics explored in Lithuania included leadership expansion at school, the leadership of school authorities and its influence on the organisation management, and other.

The problem of the research. The changes taking place in the education system of Lithuania call for research in the practices of leadership in different school types. The issue of teacher leadership has been analysed quite extensively, yet the phenomenon of leadership in progymnasium is a little researched area, and there is a lack of empirical research into the expression of leadership of the heads of schools in that school type. For a progymnasium as an educational organization, changes and their effective management are important as the determinants of the quality of education. The social context of leadership encourages exploration of how the heads - leaders of progymnasiums change staff expectations in relation to the school goals and teamwork and how their leadership competencies manifest themselves in terms of the community members' lifelong learning and a new school management culture. The present research does not aim to compare the leadership of the heads of progymnasiums with the leadership of the heads of other school types. The research focuses on the expression of the leadership competence of the heads of progymnasiums and its correlation with making that type of school more effective. The research into the issue is significant from a scholarly viewpoint because it helps to accumulate scientific information about the leadership of the heads of progymnasiums as a factor in making school activities more effective. The research from that viewpoint is valuable for the quality implementation of basic education, as it reveals practical opportunities for the leadership development in progymnasiums. In the article, the research problem has been formulated by the question: How does the leadership competence of the heads of progymnasiums promote making that school type more effective?

The topic of the research is the leadership competence of the heads of progymnasiums in the process of making that school type more effective. The aim of the research is to reveal the leadership competence of 
the heads of progymnasiums as a factor of making that school type more effective. The research methods include the analysis and synthesis of scientific literature and documents; questionnaire survey, statistical data analysis, and summation of the research findings.

The research is based on the theoretical provision of leadership (Marzano et al., 2011) regarding its significance for the development and progress of school and society. Teacher leadership is important for an educational institution striving to perform successfully and effectively, while an opportunity of developing and maintaining a high quality learning environment without professional leaders is minimal (Lewis, Hill, 2012). The authors also draw on the theory of positivism (Conte, 1892) seeking to describe phenomena rather than to answer the question of whether they exist or not. Creswell (2009) who developed the ideas of positivism noted that quantitative research was appropriate for revealing relationships between various attributes. Based on that positivist provision, empirical research was conducted, and the correlation between the leadership competences of the heads of progymnasiums and making school more effective were explored.

\section{The phenomenon of leadership in an educational institution.}

Systematic research in leadership began in the mid-20th century (Valuckiene et al., 2015). Leadership means different things to different people in different contexts, yet it is basically always defined as a process of influence that changes the behaviour of individuals or their groups (Yukl, 2012), especially in pursuit of common goals (Northouse, 2016). According to Storey (2016), the concept of leadership is constantly changing, and new approaches to leadership are emerging as well as its varieties and types. Transactional (Northouse, 2009) and transformational theories of leadership (Martin, 2011) which underpin the effectiveness of leadership (Odumeru, James, 2013; Cibulskas et al., 2011) are particularly relevant today. According to Skarbaliene (2015, p.143), leader seeks to transform the staff's expectations, change their attitudes and needs in line with the organisational goals, clearly presents the ways to achieve the intended goals, and encourages teamwork while revealing the potential of each team member.

As stated by Katiliūte, Valuckiené, and others (2012), when examining the concept of leadership in the context of education, a provision to be kept in mind is that the school organisation is a system for which change, transformation, and the process of continuous learning are important, therefore leadership plays a very important role in it. Lambert (2011) understands leadership as mutual and purposeful learning in an educational community where every individual has the right, ability, and responsibility to be a leader and to engage in certain activities. Cibulskas and Židžiūnaitė (2012) note that, in an educational institution leaders play the role of determined guides in the realisation of goals.

As argued by Baranauskas and others (2013), effective change management in an educational institution is mainly related to the involvement of all community members in activities, continuous improvement, and effective leadership that determines the unity of the whole community and the quality of education. According to Storey (2016), in order to achieve the best results, the expression of leadership must take place at all levels of school. Kapur indicates that (2018), as the research base keeps growing, teachers increasingly understand how and in what way leadership in an educational institution can contribute to pupils' academic performance. Everard et al. (2014) are inclined not to identify leadership solely with the heads of schools and argue that the position of leader can be held by any member of the community, and that should be encouraged.

\section{Leadership competence of the heads of progymnasiums} in the context of making school more effective.

A successful contemporary school should not only apply an effective teaching / learning model, but also be effectively managed. A systematic approach to school management is one of the requirements for an effective school of the 21st century (Storey, 2016). A clear vision of the school, understanding of the trends in the field of education and the requirements arising from them, the ability to identify and adapt resources to the school-related problem solution results in anticipating potential challenges and overcoming them. 
Effective school performance management directly predetermines positive changes: a commitment of seeking success for all; improved flexibility and responsiveness to emerging problem situations; improvement of the climate in an educational institution, promotion of learning; and better interpersonal relationships within the school community (Nzoka et al., 2014: 89).

The aim of a contemporary progymnasium is to organise its activity efficiently and purposefully, to mobilise the school community for the solution of topical educational problems, to anticipate the ways of implementation of the requirements for educational activities, to decide on the necessary directions and priorities of activity as well as to anticipate and plan changes in teaching /learning (Valstybiné švietimo 2013-2022 metų strategija, 2014).

As noted in the Good School Concept (LR ŠMM ministro ịsakymas „Dèl geros mokyklos koncepcijos patvirtinimo", 2015), the aspects of the activity of school as an organisation - educational environment, education (teaching), staff, community and its learning, leadership, and management - are the factors that predetermine the implementation of the school's mission. These factors are important, however, they are only conditions for the implementation of the mission, while good results can be achieved by working in different ways and by different organisation of the school activity. The progymnasium is to comply with the definition of the Good School Concept (LR ŠMM ministro ịsakymas „Dèl geros mokyklos koncepcijos patvirtinimo“, 2015), i.e. be a school that pursues the purport, discoveries, and academic excellence and whose activity is to be based on community agreements and learning. Given these documents, the progymnasium, as a general education school providing basic education, is to meet the requirements for a contemporary educational institution, to direct its activities toward effective management, and to strive for the quality of education. By developing activities that meet the needs of the contemporary society, the progymnasium can and must contribute to the formation of a new school management culture, which today is difficult to imagine without leadership and lifelong learning.

The performance of a progymnasium, as well as of any other school type, is influenced by its independence and the expansion of leadership which encourages the pursuit of high quality teaching / learning (Cibulskas et al., 2011). According to Mečkauskienè (2010), management is more often associated with the assurance of stability and order in school as well as with the effective implementation of leadership, control, planning, and organisational functions. Meanwhile, leadership is associated with the social context, the processes of ensuring school change, anticipating its prospects and vision, the processes of responsibility distribution, and the competence of the school authorities / leaders (Cibulskas et al., 2011, p. 47).

Researchers (McCrey et al., 2014; Nzoka et al., 2015; Storey, 2016 et al.) emphasise the functionality of school being predetermined by its management. Important aspects of progymnasium management are likely to include constant encouragement of positive pupil behaviour (Malinauskienè et al., 2012); a successfully built image of the school (Želvys, 2003); and properly organised and conducted parental education (Yukl, 2012). As in the case of any other school types, for the effective management of a progymnasium, it is important to effectively manage not only its activity but also the related risks, to apply the curriculum flexibly, and to focus on team building and leadership in it (Everard et al., 2014, p.122).

In the context of the progymnasium, some scholars" ideas on leadership seem to be relevant. Marzano et al. (2011) recognise leadership as one of the factors predetermining success in many school areas. Hargreaves and Fink (2012) relate successful leadership to school progress. Storey (2016) finds that rational organisation of education, consistent implementation of a pupils' socialisation programme as well as active communication and collaboration with the school community members, social partners, and educational institutions and / or other organisations abroad are important for the effective school management.

Šilingienè argues (2011, p. 961) that the leadership competence consists of two groups of competences: personal qualities of a leader (empathy, positive thinking, self-confidence, responsibility, etc.) and leadership skills (vision and goal formulation, emotional competence, delegation, etc.). Leadership qualities of the heads of schools determine effective management of human resources and activities, ensure the well-being, safety, and social protection of the staff, and encourage the development of a harmoniously functioning educational institution at all levels (Rajbhandari et al., 2015). In the research into contemporary leadership (Arman et al., 2016), personal qualities of the heads of institutions are found to be important for effective 
leadership, especially intellectual abilities and personal traits such as dominance, communicativeness, sociability, self-confidence, energy, etc. The qualities of long-term successful heads of schools - leaders are a prerequisite for their initiatives, increase the effectiveness of the school, and ensure the continuity of the work started and sharing of activities and responsibilities (Hargreaves et al., 2012).

Arman et al. (2016) note that the leadership competence of the heads of schools serves as a basis for improving the results of the school performance management, raising the staff motivation, and implementing changes in the education system. The research conducted by Arman and co-authors witnesses that the leadership competence of the heads of schools is revealed through five indicators: learning and achievements; leadership in the learning process; school environment management; responsibility for learning and assessment; and personal characteristics (Arman et al., 2016, p. 145).

The Order of the Republic of Lithuania Minister of Education, Science, and Sport On Approval of the Qualification Requirements for Heads of State and Municipal Educational Institutions (LR ŠMSM ministro ịsakymas „Dẻl Kvalifikacinių reikalavimų valstybinių ir Savivaldybių švietimo ịstaigų (išskyrus aukštąsias mokyklas) vadovams aprašo patvirtinimo" pakeitimo“, 2019) amended the one in force from 2011 which had identified the general competences of personal efficiency, strategic thinking and change management, the ability to learn, personnel management, communication and information competences as well as leadership competencies, including strategic management of an educational institution; management of learning; teachers professional development; and partnership and resource management in educational institutions. Based on the document analysis, it can be argued that the professionalism and managerial competences of the heads of progymnasiums are a precondition for the effectiveness of the school activity. Therefore, the knowledge of the heads of progymnasiums about the improvement of the educational process and their leadership competence can be considered as a prerequisite for the successful implementation of the school vision and goals.

According to Navickaite (2012, p. 36), the leadership competence of the heads of schools creates conditions for the development of creativity of community members and for building a learning community. The principal of the progymnasium is the key actor in establishing effective links between different levels of education and training as well as families, the labour market, and the local community with the common goal of improving pupil achievements (Bagdone, 2015). In the context of progymnasium, the idea of Rajbhandari et al. (2015) of the formation of the leadership competence as a continuous process with the aim of maintaining the effectiveness of the educational institution and strengthening the motivation of community members seems to be relevant.

The theoretical analysis of the issue creates the preconditions of looking for the correlation between the leadership competence of the heads of progymnasiums and making the school more effective as well as of justifying it empirically. The following hypothesis is to be proved: active expression of the leadership competence of the heads of a progymnasium is a factor that promotes the effectiveness of school activities in the areas of inculcation of innovations, project implementation, promotion of teacher initiatives and professional development, assurance of the coherence between the school values, mission, and vision, and mobilisation of the community members for common activities.

\section{Research methodology}

In order to achieve the aim of the research - to reveal the leadership competence of the heads of progymnasium as a factor in making school more effective - quantitative research was conducted. According to Kardelis (2016), quantitative research is characterised more by a normative paradigm, while a quantitative analysis is an instrument that can confirm (or refute) certain assumptions, and its scientific value is predetermined by the fact that it provides quantitative indicators; that kind of research is structured, and the instruments of measuring the research data are considered in advance and planned. The phenomenon of the progymnasium heads ' leadership exists independently of researchers, and the quantitative research aims to reveal not the nature of the phenomenon, but rather the correlation between the progymnasium heads' leadership competence and the school activity management: the information obtained through the research is generalised. 
The research was carried out in 9 progymnasiums of the western region of Lithuania (Klaipeda, Šilute, Kretinga, Tauragè); a (written) questionnaire survey was selected as the research method. The sample of the quantitative research consisted of 193 progymnasium teachers selected by convenience sampling. The said sampling method was chosen because convenience sampling „,...) included those units of the general set that were easily available“ (Valackienè et al., 2008: 59). A questionnaire was developed for the research, based on works by Marzano et al., (2011), McCray et al. (2014), Storey (2016), and other experts on leadership in numerous school areas, the role of the heads of schools as leaders in school management, and the school as a system for which change, transformation, and a continuous learning process were important and leadership was relevant. Cronbach's alpha coefficient was calculated which reflected the validity of the research instrument and the internal coherence of the scales. The survey questionnaire was developed appropriately and was reliable, since the value of the Cronbach's alpha coefficient was equal to 0.924 . The research data were analysed and systematised using SPSS 20 program. For data distribution on the nominal and ordinal scales, a percentage frequency distribution was calculated; to identify variable relationships, the Spearman correlation coefficient was calculated (Bitinas, 2013).

\section{Research findings}

The analysis of the demographic characteristics of the research participants revealed that the progymnasium teachers were mature and educated and therefore they were believed to have sufficient competences to evaluate the expression of the leadership competence of the heads of their schools in terms of making schools more effective. The article presents not all the research findings but only those that reveal the essence of the issue.

The respondents-progymnasium teachers $(\mathrm{N}=193)$ evaluated the expression of the leadership competence of the heads of their schools in several aspects: the leadership competence was most pronounced in the progymnasium's participation in projects $(87.6 \%)$; adoption of innovations $(86.5 \%)$; creation of favourable conditions for teachers' initiatives to be implemented (85.0\%); and encouragement of community members to participate in the self-assessment process $(84.9 \%)$. An insignificantly smaller percentage of the teachers identified some other features of the expression of the progymnasium heads' leadership: in the progymnasium, great attention was paid to the quality of education (83.4\%); community members were involved in setting the daily activity goals (83.3\%); enterprising staff were supported and encouraged (83.3\%); and good relations were maintained with social partners (80.3\%). Fewer teachers indicated that the leadership competence of the heads of their progymnasium was manifested through creating conditions for the staff personal development, regular self-evaluation of performance, allocation and effective use of funds, involvement of community members in the development of the progymnasium vision, promoting the staff creativity, and ensuring the continuity of work planning, based on the results of the self- or external performance evaluation. It can be argued that the leadership competence of the heads of the progymnasiums was manifested in various fields; the respondent teachers held positive views of the project activities, adoption of innovations, creation of conditions for initiatives, self-evaluation, and professional development, and good relations with social partners. However, according to the teachers, the leadership competences of the heads of their progymnasiums were less pronounced in the involvement of community members in the vision building, using funds more efficiently, encouraging the staff creativity, and ensuring regular self-assessment and the continuity of work planning.

Moreover, as established by the research, the leadership competence of the heads of the progymnasiums accounted for promotion of the staff professional development $(88.0 \%)$, the process of progress and achievement evaluation (87.0\%), teachers' initiatives $(86.6 \%)$, and the coherence of the values, mission, and vision of the educational institution (85.0\%). Insignificantly fewer progymnasium teachers noted that the leadership competence of the school heads had an impact on the continuous improvement of the school organisation (83.9\%), collaboration between teachers $(80.8 \%)$, and the quality of pupils' learning $(80.3 \%)$. The teachers associated the leadership competence of the school heads with the managerial competences, and as many as $77.0 \%$ of the respondents believed that the progymnasium heads had developed the said competences. The findings of the research regarding the leadership competence of the progymnasium heads being responsible for the 
promotion of teachers' professional development, evaluation of children's achievements, the coherence of the school values, mission, and vision and their implementation as well as the quality of education and collaboration suggested that the leadership competence of the school heads was a factor in effective school management.

The research revealed the correlation between the leadership competence of the progymnasium heads and making school more effective. From the viewpoint of the respondent teachers, the leadership competence of the heads of their progymnasiums had the greatest influence in the following areas: making parents / guardians/ caregivers more active (88.7\%); strengthening communication and collaboration between community members $(88.1 \%)$; promoting staff initiative and independence (87.5\%); positively influencing pupils ${ }^{6}$ learning motivation (86.6\%); building sustainable relationships with social partners $(83.4 \%)$, and involving community members in key decision-making (82.9\%). Of all the features reflecting the management of progymnasium activities, the predominating one was making activities with parents more effective, which created conditions for their participation in educational and other activities and encouraged them to take a joint responsibility for issues important to the school. No less important was the promotion and support of active cooperation between members of the progymnasium community. It can be argued that one of the main responsibilities of the head of a progymnasium as a leader was the development of sustainable interpersonal relationships within the school community as a precondition for the effective management of progymnasium activities.

A smaller part of the teachers believed that the leadership competence of the progymnasium heads had an impact on making school more effective since it empowered pupils' self-government (77.7\%); the heads took care of a good infrastructure and equipment of the progymnasium (77.7\%) and distributed bonuses and salary supplements for extra work or extraordinary achievements $(74.0 \%)$ It should be noted that a smaller number of the respondents saw the influence of the heads' leadership competence when evaluating other important indicators representing quality performance: pupils" positive view of the education quality and environment (65.3\%); a high number of successful progymnasium graduates and their enrollment in gymnasiums (64.7\%); and good results of standardised learning outcomes assessment tests (63.8\%). The obtained findings led to the conclusion that the effectiveness of the progymnasium activity management was more often related to the material or social aspects; less often the correlation between the effective management of the progymnasium activity with students' learning achievements and other indicators representing the school performance, which could be considered as evaluation criteria witnessing the effectiveness of the school activity, was identified.

The research results suggested that the progymnasium heads" leadership competence in making school more effective was mainly manifested through the collaboration between the progymnasium community members, promotion of the staff initiative and independence, strengthening pupils' learning motivation and sustainable relationships with social partners, unity in key decision making, empowering of pupils` self-government, and staff motivation. Merely more than half of the survey participants saw the expression of the heads leadership competence in such important traits of making school more effective as pupils' positive view of the quality of education and environment, a high number of successful progymnasium graduates continuing in gymnasiums, and good results of standardised learning outcomes assessment tests. An assumption can be made that the heads of the progymnasium, through concentrating on the school performance management, created conditions for teachers to make the education process more effective in order to achieve good learning outcomes.

Spearman correlation calculations revealed statistically significant, positive, weak correlations between the age of the research respondents and the item about the progymnasium heads' leadership competence expression in terms of pupils' academic performance $(\mathrm{r}=0.248)(\mathrm{p}=0.05)$ and good results of standardised learning outcomes assessment tests $(\mathrm{r}==0.248)(\mathrm{p}=0.05)$. One can argue that the older teachers are, the more they tend to believe that the heads 'leadership competence has an impact on pupils ' good learning outcomes and good results of standardized learning outcomes assessment tests. A statistically significant, positive, weak correlation was also established between the qualification category of the research participants and the item about the influence of the leadership competence on the involvement of the progymnasium community members in the development of the progymnasium vision $(r=0.241)(p=0.05)$. The interpretation of the correlation witnessed that the higher the qualification category of teachers, the more they believed that the heads involved the progymnasium community members in the development of the vision of the edu- 
cational institution. A statistically significant, negative, weak correlation was found between the teachers' qualification category and the item about the leadership competence of the heads making parents / guardians/ caregivers more active $(\mathrm{r}=-0.334)(\mathrm{p}=0.05)$. It can be argued that the lower the qualification category of the teachers, the more they tend to believe that the leadership competence of the progymnasium authorities predetermine the involvement of parents / guardians/ caregivers in school activities.

Sumary of the research findings. The research revealed that the leadership competence of the heads of progymnasiums was manifested in various fields, especially in projects, adoption of innovations, promotion of teacher initiatives, self-evaluation process, etc. The leadership competence of the heads was less pronounced in the involvement of community members in the vision building, promotion of staff creativity, ensuring regular self-evaluation, and continuity of work planning. The research findings were close to Storey's (2016) idea that, in order to achieve the best results, the expression of leadership must be felt at all levels of the school. In the context of change, the school heads should concentrate resources in all areas of the school in order to achieve long-term results and increase the school effectiveness (Nzoka et al., 2014).

The research revealed that the leadership competence of the progymnasium heads promoted the involvement of parents / guardians/ caregivers, professional development of teachers, assessment of children's achievements, coherence of the school values, mission, and vision, quality of education, and collaboration. That demonstrated the correlation between the heads' leadership competences and making the school more effective. The research findings confirmed the conclusions of the research carried out by Arman et al. (2016, p. 45) to the effect that the leadership competence of the school heads was revealed through school management as well as the idea of other researchers that communication with parents created conditions for their more active participation in educational activities and encouraged joint responsibility for school-important issues (Nzoka et al., 2014), since one of the main responsibilities of the heads of the educational institution was the development of sustainable interpersonal relationships in the community (Everard et al., 2004).

The research revealed the correlation between the leadership competence of the progymnasium heads and the effectiveness of the school activity. The leadership competence mainly accounted for the promotion of collaboration between the community members, pupil learning motivation, sustainable relationships with social partners, unity, etc. Other researchers (Cibulskas et al., 2012, p. 47) also related the effectiveness of school activity with the social context, ensuring school change and anticipation of the prospects and vision, and the competence of the head of the school as leader. The research proved that, from the teachers' point of view, the leadership competence of the heads was less responsible for other indicators of making their schools more effective, such as a high number of successful progymnasium graduates who continued in gymnasiums, good results of standardised learning outcomes assessment tests, etc. According to McCray et al. (2014), the indicators of the pupil academic achievements were precisely those evaluation criteria by which the school effectiveness could be judged.

In the case of the current research, the age of the progymnasium teachers and the acquired qualification category were statistically significant in evaluating the influence of the leadership competence of the progymnasium heads on the effectiveness of the school activities. The teachers with higher education and a higher qualification category were more critical in the evaluation of the leadership competence of their school heads in making the school more effective than their colleagues with lower education. The teachers with higher education had a better insight into the areas for improvement when evaluating the correlation between the leadership competence of the heads and the effectiveness of the school activities. It is likely that, in the expression of the leadership competence of their school heads, the teachers saw opportunities for the expression of their own leadership in making their progymnasium more effective.

The present study is expected to contribute to the development of research in the field of education management and leadership; it creates preconditions for further research intended to evaluate the leadership competence not only of the heads, but also of the teachers of progymnasiums and its impact on making comprehensive education more effective. In terms of education policy, the study is useful as it shows the importance of facilitating the lifelong learning of teachers with the aim of improving their leadership as well as other general and professional competencies, developing inter-institutional cooperation, and implementation of joint projects. 


\section{Conclusions}

The research revealed that mobilising human and material resources for educational success and progress was the most important feature of progymnasium heads ' leadership (in the opinion of teachers). The leadership competences of the progymnasium heads were manifested in a variety of areas, particularly in organising projects, implementing innovations, and promoting teacher initiatives and the self-evaluation process.

The leadership competence of the progymnasium heads was an incentive for parents / guardians/ caregivers to become more actively involved in school activities as well as for teachers" professional development, evaluation of pupils' achievements, coherence of the school values, mission, and vision, and the improvement of the quality of education and expansion of cooperation.

Such expression of the heads" leadership competence should be considered as active and encouraging community members to share responsibility in the process of making schools more effective. The influence of the leadership competence of the progymnasium heads on making school more effective was manifested in the social context, i.e. in promoting the collaboration between, and the unity of, community members, building and maintaining sustainable relationships with social partners, etc.

The age, education, and qualification category of the research participants were statistically significant aspects in evaluating the expression of the progymnasium heads' leadership competence and its correlation with effective school activity. The research revealed that the expression of the leadership competence of the progymnasium heads was quite active and represented a factor that promoted the process of making school more effective in various fields.

\section{References}

Arman, S. T., Darman, M. (2016). The effect of school supervisors competence and school principals competence on work motivation and performance. International Journal of Environmental \& Science Education, Vol 11 (15), p. 7309-7317. Ebsco publishing.

Bagdonė, I. (2015). Šiuolaikinės mokyklos valdymas. Švietimo problemos analize, Nr. 2(126), p. 1-12.

Baranauskas, R., Zasčiurinskaitė, I. (2013). Švietimo ịstaigų vadovams reikalingos lyderystès savybės ir gebejjimai: teorinis diskursas. Aktualios akademinio jaunimo ugdymo problemos tyrimuose. Sud. I. Tandzegolskienė, A. Rutkienė. Kaunas: VDU, p. 109-117.

Bendrojo ugdymo mokyklu veiklos kokybè. Nacionalinès mokyklu vertinimo agentūros metinis pranešimas. (2015). Retrieved from: http://www.nmva.smm.lt/wp-content/uploads/2012/12/Metinis-prane\%C5\%A1 imas-maketas- 02.04.pdf

Bitinas, B. (2013). Rinktiniai edukologiniai raštai. T. 2. Edukologinis tyrimas: sistema ir procesas. Vilnius: Edukologija.

Cibulskas, G., Žydžiunaitė, V. (2012). Lyderystès vystymosi mokykloje modelis. Vilnius: Lodvila.

Everard, K. B., Morris, G., Wilson, I. (2004). Effective school management. Retrieved from: https://uk.sagepub.com/ en-gb/eur/effective-school-management/book226510\#

Creswell, J. W. (2009). Research design: Qualitative, Quantative and mixed methods approaches (3rd ed.). London: Sage Publications.

Haynes, N. M., Arafeh, S., McDaniels, C. (2014). Educational leadership: perspectives on preparation and practice. Retrieved from: https://books.google.lt/books?hl=lt\&lr=\&id=ih8JBgAAQBAJ\&oi=fnd\&pg=PA $253 \& \mathrm{dq}=$ leadership + in + education\&ots=x-DfEATL0X\&sig=wMN1SwrGQKraCXtiLDnzLvb3E0\&re dir esc $=\mathrm{y} \# \mathrm{v}=$ onepage $\& \mathrm{q}=$ leadership $\% 20 \mathrm{in} \% 20$ education $\& \mathrm{f}=$ false

Hargreaves, A., Fink, D. (2012). Sustainable leadership. Retrieved from: https://scholar.google.lt/scholar?start=40\&q= Leadership+competence+asa+factor+in+school+efficiency+boost\&hl=lt\&as_sdt=0,5\&as_vis=1

Yukl, G. (2012). Effective Leadership Behaviors: What We Know and What Questions Need More Attention? The Academy of Management Perspectives. Ebsco Publishing.

Kardelis, K. (2016). Moksliniu tyrimu metodologija ir metodai. Vilnius: Mokslo ir enciklopedijų leidybos centras.

Katiliūtè, E., Beresnevičiūtè, V., Ramonienè, L., Valuckienė, J. (2012). Longitudinio Lietuvos švietimo lyderystės raiškos tyrimo metodologija ir instrumentai. Vilnius: Standartų spaustuvè.

Lambert, L. (2011). Lyderystès gebejimai ir tvari mokyklos pažanga. Vilnius: Vitae Litera.

Lietuvos Respublikos švietimo ịstatymas, Nr. 38-1804. (2011). Teisės akto redakcija ịsigalioja nuo 2020-01-01. Retrieved from: http://www.infolex.lt/ta/54723:str41

Lietuvos Respublikos Seimo nutarimas „Dèl valstybinès pažangos strategijos „Lietuvos pažangos strategija „Lietuva 2030" patvirtinimo“, Nr. XI-2015. (2012). Retrieved from: https://e-seimas.lrs.lt/portal/legalAct/lt/TAD/ TAIS. 425517 
Lietuvos Respublikos švietimo ir mokslo ministro isakymas „Dèl geros mokyklos koncepcijos patvirtinimo“, 2015 m. gruodžio 21 d., Nr V-1308. Vilnius. Retrieved from: <https://www.etar.lt/portal/lt/legalAct/f2f65120a7>

Lietuvos Respublikos švietimo, mokslo ir sporto ministro įsakymas „,Dèl švietimo ir mokslo ministro $2011 \mathrm{~m}$. liepos $1 \mathrm{~d}$. isakymo Nr. V-1194 „Dèl kvalifikaciniu reikalavimu valstybiniu ir Savivaldybiu švietimo ịstaigu (išskyrus aukštasias mokyklas) vadovams aprašo patvirtinimo " pakeitimo “, 2019 m. balandžio 19 d., Nr. V-456, Vilnius. Retrieved from: https://www.e-tar.lt/portal/lt/legalAct/a93d7c30629c11e99676cb74c51fe1f4

Malinauskienė, D., Augienė, D. (2012). Mokyklos vadovų lyderių savybių raiška mokyklų bendruomenės veikloje (pedagogų nuomonès tyrimas). Mokytojų ugdymas, Nr. 15 (2), p. 134-145. Retrieved from: <http://vddb.library.lt/ fedora/get/LT-eLABa-0001:J.04 2010 ISSN_1822-119X.N_15_2.PG_1ž34-145/DS.002.0.01.ARTIC>

Marzano, R. J., Waters, T., McNulty, B. A. (2011). Veiksminga mokyklų lyderystè. Nuo moksliniu tyrimu iki rezultatų. Vilnius: Vilniaus pedagoginio universiteto leidykla.

McCray, C. R., Beachum, F. D. (2014). School Leadership in a Diverse Society: Helping Schools Prepare All Students for Success. Retrieved from: http://ezproxy.biblioteka.ku.lt:3672/ehost/detail/detail?vid=6\&sid=2ca175f7-7a0a417e-bd2cbbfdc1ed7706\%40sessionmgr4005\&hid=4104\&bdata=JnNpdGU9ZWhvc3QtbG12ZQ $\% 3 \mathrm{~d} \% 3 \mathrm{~d} \# \mathrm{db}=\mathrm{nle}$ bk\&AN=688072

Navickaitė, J. (2012). Mokyklos vadovo lyderystė vykstančių švietimo pokyčių kontekste. Acta Paedagogica Vilnensia, Nr. 29, p. 35-46.

Nedzinskaite, R. (2015). Mokytojas kaip transformacinis lyderis: faktas ar fikcija. Švietimo problemos analize, p. 1-8. Retrieved from: https://www.smm.lt/uploads/documents/tyrimai_ir_analizes/SPA $\% 202015 \% 20$ sausis $\% 20 \mathrm{Nr} 5 \% 20$ (129).pdf

Northouse, P. G. (2016). Leadership: Theory and practice. Thousand Oaks, CA: Sage.

Nzoka, J. T., Orodho, J. A. (2014). School Management and Students'Academic Performance: How Effective are Strategies being Employed by School Managers in Secondary Schools. International Journal of Humanities and Social Science, Vol. 4, No. 9, p. 86-99. Retrieved from: http://www.ijhssnet.com/journals/Vol_4_No_9_July_2014/9.pdf

Odumeru, J., Ogbonna, I. G. (2013). Transformational vs. Transactional Leadership Theories: Evidence in Literatur. International Review of Management and Business Research, Vol. 2, p. 355-361. Retrieved from: http://www.irmbrjournal.com/papers/1371451049.pdf

Progimnazijų ir pagrindinių mokyklų paskirtis ir vieta bendrojo ugdymo sistemoje. (2016). Parengè A. Gražytè. Švietimo problemos analize, Nr. 2 (145), p. 1-12. Retrieved from: http://www.nmva.smm.lt/wp-content/uploads/2012/12/ progimnazijos.pdf

Rajbhandari, M. M. S., Rajbhandari, S. (2015). Leadership Maintenance: Filling the Gap for Leadership Competences. AcademicJournals. Educational Research and Reviews, Vol. 10(21), p. 2777-2788. Retrieved from: http://files.eric. ed.gov/fulltext/EJ1084151.pdf

Savareikiené, D. (2013). Transformational leadership roles in the development of motivation in aspects of good governance. Ekonomika ir vadyba: aktualijos ir perspektyvos, Nr. 3(31), p. 152-158. Retrieved from: http://www. su.1t/bylos/mokslo_leidiniai/ekonomika/2013_3_31/savareikiene.pdf

Storey, J. (ed.) (2016). Leadership in Organizations - Current issues and key trends. London: Routledge. Retrieved from: http://oro.open.ac.uk/44224/1/Chapter\%202.\%20Changing\%20Theories\%20of\%20Leadership\%20.pdf

Skarbalienè, A. (2015). Lyderystè, autoritetas ir moralinès vertybės postmodernizmo kontekste. Logos, Nr. 83, p. $140-147$.

Šilingienè, V. (2012). Lyderystè. Kaunas: Technologija.

Valstybinè švietimo 2013-2022 metu strategija. (2014). Švietimo ir mokslo ministerija. Vilnius: ŠAC. Retrieved from: https://www.sac.smm.lt/wp-content/uploads/2016/02/Valstybine-svietimo-strategija-2013-2020_svietstrat.pdf

Valuckienè, J., Balčiūnas, S., Katiliūtè, E., Simonaitienė, B., Stanikūnienè, B. (2015). Lyderystè mokymuisi: teorija ir praktika mokyklos kaitai. Retrieved from: https:/www.sac.smm.lt/wp-content/uploads/2016/01/Lyderyste-mokymuisi_teorija-ir-praktika-mokyklos-kaitai.pdf

Želvys, R. (2003). Švietimo organizacijos vadyba. Vilnius: Vilniaus universiteto leidykla. 


\title{
PROGIMNAZIJOS VADOVO LYDERYSTES KOMPETENCIJA - MOKYKLOS VEIKLOS VALDYMO EFEKTYVUMO VEIKSNYS
}

\author{
Lilia ŽuKauskiené, AureliJa MaciJauskienĖ \\ Klaipèdos universitetas (Lietuva)
}

\section{Santrauka}

Lietuvos švietimo sistemoje iki 2012 metų įvyko nemažai pokyčių, vienas jų - LR Švietimo ịstatymu (2011, 41 str. 2 d.) įteisinta nauja mokyklų tinklo struktūra, numatytas naujas mokyklos tipas - progimnazija, kurioje lyderysté tapo siekiu, kaip ir visose švietimo sistemos grandyse. Mokytojų lyderystės problema gana plačiai analizuojama, bet trūksta empirinių tyrimų, kurie būtų skirti lyderystės reiškiniui progimnazijos kontekste.

Mokslinė problema formuluojama klausimu: kaip progimnazijos vadovo lyderystės kompetencija skatina šio tipo mokyklos veiklos veiksmingumą? Tyrimo tikslas - atskleisti progimnazijos vadovo lyderystès kompetenciją, kaip šio tipo mokyklos veiklos veiksmingumo veiksnį. Tyrimo metodai: mokslinès literatūros ir dokumentų analizė bei sintezé; anketinè apklausa, statistinè duomenų analizè, tyrimo rezultatų apibendrinimas.

Straipsnyje, remiantis moksliniais tyrimais, analizuojami trys problemos aspektai: lyderystès reiškinys švietimo institucijoje; efektyvus veiklos valdymas, kaip šiuolaikinès progimnazijos siekis; progimnazijos vadovo lyderystės kompetencijos ir veiklos veiksmingumo ryšys. Pateikiami kiekybinio progimnazijos vadovų lyderystės kompetencijos ir mokyklos veiklos efektyvinimo sąsajų tyrimo rezultatai. Kiekybinio tyrimo imtį sudare 193 progimnazijų mokytojai, atrinkti taikant patogiają atranką. Tyrimas vyko 9-iose Lietuvos Vakarų regiono (Klaipèda, Šilutè, Kretinga, Tauragė) progimnazijose.

Tyrimo rezultatai. Progimnazijų vadovų lyderystès tyrime atskleistas jos skatinamasis bruožas, telkiantis žmogiškuosius ir materialinius išteklius, siekiant sèkmingo ugdymosi ir pažangos. Progimnazijų vadovų lyderystės kompetencija reiškiasi ịvairiose srityse, ypač organizuojant projektus, diegiant naujoves, skatinant mokytojų iniciatyvas ir ịsivertinimo procesą. Lyderystès kompetencija yra paskata tėvams / globejjams / rūpintojams aktyviau ịsitraukti ị mokyklos veiklą, profesinio tobulejimo siekiantiems mokytojams, taip pat siekiant ịvertinti vaikų pasiekimus, vertybes, misijos ir vizijos darną, norint gerinti ugdymo kokybę ir plètoti bendradarbiavimą. Progimnazijos vadovų lyderystès kompetencijos įtaka mokyklos veiklos veiksmingumui pasireiškia socialiniame kontekste, t. y. skatinant bendruomenės narių bendradarbiavimą ir sutelktumą, kuriant ir palaikant tvarius santykius su socialiniais partneriais ir kt. Tyrimo dalyvių amžius, išsilavinimas ir igyta kvalifikacinè kategorija yra statistiškai reikšmingi aspektai, vertinant progimnazijos vadovo lyderystès kompetencijos raišką ir ryši su mokyklos veiklos veiksmingumu. Tyrimas atskleidè, kad progimnazijų vadovų lyderystės kompetencijos raiška yra gana aktyvi ir laikytina mokyklos veiklos efektyvinimą ịvairiose srityse skatinančiu veiksniu.

PAGRINDINIAI ŽODŽIAI: progimnazija, vadovas, lyderystès kompetencija, veiklos efektyvinimas. 